\title{
Solitary Langerhans Cell Histiocytosis of the Rib
}

\section{Kostada Soliter Langerhans Hücreli Histiositozis}

Demet Yaldı' ${ }^{1}$, Mehmet Sadık Yaldız', Peyker Temiz², Cihan Göktan ${ }^{3}$

\section{Abstract}

Isolated rib involvement is one of the rarest sites for the clinical presentation of Langerhans cell histiocytosis $(\mathrm{LCH})$. We report here on the case of 29-year-old female whose only symptom was pain, radiating to the solitary osteolytic lesion at the posterolateral aspect of her seventh rib. The 7th rib was resected for diagnostic confirmation and treatment, and histopathological findings were found to be compatible with the $\mathrm{LCH}$.

Key words: Langerhans Cell Histiocytosis, rib, surgery.

\section{Özet}

İzole kosta tutulumu, Langerhans hücreli histiyositozisin $(\mathrm{LCH})$ en nadir tutulum bölgelerinden biridir. Biz burada, tek yakınması sol 7. kostanın posterolateral bölgesinde soliter osteolitik lezyona bağlı ağrı olan, 29 yaşında bir kadın olguyu sunuyoruz. Hastada 7. kosta, tanı ve tedavi amaçlı rezeke edildi. Histopatolojik bulgular LCH ile uyumlu bulundu.

Anahtar Sözcükler: Langerhans hücreli histiositozis, kosta, cerrahi.
'Department of Thoracic Surgery, Manisa Celal Bayar University, Manisa, Turkey

${ }^{2}$ Deparment of Pathology, Manisa Celal Bayar University, Manisa, Turkey

${ }^{3}$ Department of Radiology, Manisa Celal Bayar University, Manisa, Turkey
'Manisa Celal Bayar Üniversitesi Tıp Fakültesi, Göğüs Cerrahisi Anabilim Dalı, Manisa

${ }^{2}$ Manisa Celal Bayar Üniversitesi Tıp Fakültesi, Patolii Anabilim Dalı, Manisa

${ }^{3}$ Manisa Celal Bayar Üniversitesi Tıp Fakültesi, Radyoloji Anabilim Dalı, Manisa

Submitted (Başvuru tarihi): 27.03.2020 Accepted (Kabul tarihi): 28.04.2020

Correspondence (iletişim): Demet Yaldız, Department of Thoracic Surgery, Manisa Celal Bayar University, Manisa, Turkey

e-mail: demetyaldiz@gmail.com 
Langerhans cell histiocytosis is a reactive proliferative disease of unknown etiology characterized by a proliferation of Langerhans cells. It involves mostly bone, lung, liver, skin, central nervous system, lymph node and thymus (1). Bone involvement mostly occurs in the skull, followed in prevalence by the femur, jaw, pelvis, spine, scapula, humerus and sternum (2). Though rare, cases of $\mathrm{LCH}$ of the rib have been reported $(3,4)$.

\section{CASE}

A 29-year old female presented to the clinic with a leftsided pain for almost 6 months in the posterolateral aspect of the seventh rib. There was no history of trauma or disease. Upon physical examination, no swelling or fluctuation was demonstrated over the7th rib area. Laboratory tests were normal. A chest $X$-ray revealed an expansile shadow on the lateral aspect of the seventh rib (Figure 1). A computed tomography (CT) scan revealed a destructive osteolytic lesion on the left 7th rib (Figure 2). Both benign and malign lesions of the rib were considered in the differential diagnosis. For diagnostic confirmation and treatment, a wide resection of the seventh rib with a tumor-free margin was performed. Upon histopathologic examination, no malignant cell was detected. Clusters of histiocytes with a reniform vesiculated nucleus and abundant foamy cytoplasm with numerous eosinophils confirmed the diagnosis of LCH (Figure 3). The patient had experienced no local recurrence or metastasis one year after the operation.

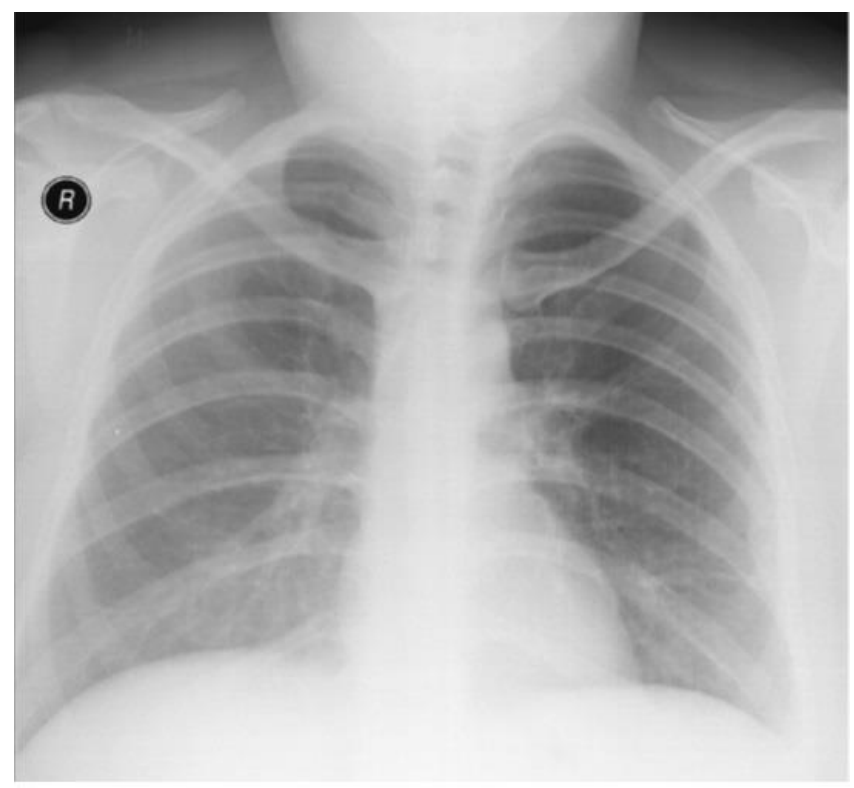

Figure 1: An expansile shadow was noted on the lateral aspect of the seventh rib (arrow)

\section{DISCUSSION}

$\mathrm{LCH}$ is characterized by an abnormal proliferation of tissue macrophage referred to as Langerhans cells. Since the etiology is still unknown, the most important question was whether the lesion is benign or malignant, or a reactive disease of activated Langerhans cells in an immune response. Since there have been very few studies of this subject to date, and none can be considered definitive, it is very difficult to resolve this issue (5). LCH is most commonly seen in children, with $80 \%$ of cases occurring in those under the age of 15 (6).

The clinical patterns of LCH are varied, and may affect single regions or different organs, being known to affect bone, lung, liver, central nervous system, thymus, lymph node and skin (1). Single solitary lesions on the rib, however, are extremely rare, with few studies reporting cases of this nature $(3,4)$. Although it's clinical pattern may be varied, there is a strong tendency for the formation of an osteolytic lesion on the bone. Differential diagnoses of osteolytic lesions must consider multiple myeloma, primary bone malignancy, lymphoma, metastasis and osteomyelitis, and LCH also should be considered in the differential diagnosis of osteolytic lesions occurring in the rib.

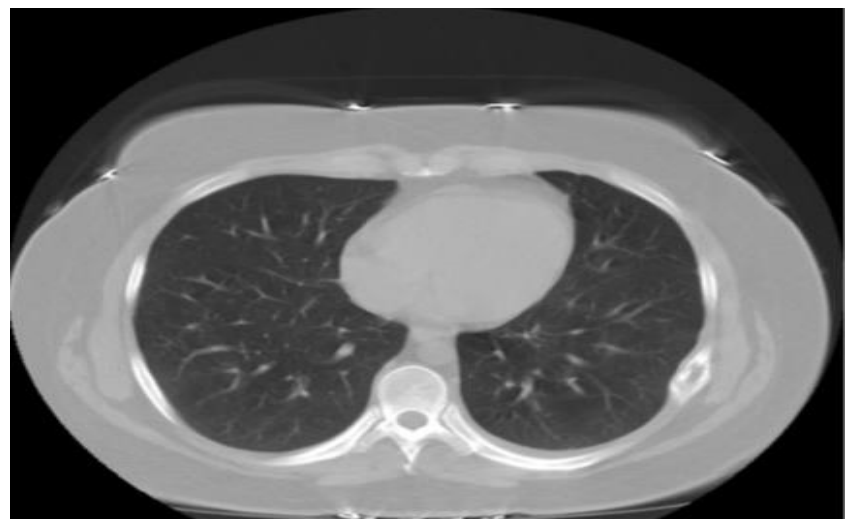

Figure 2: A destructive osteolytic lesion on the left 7th rib was noted

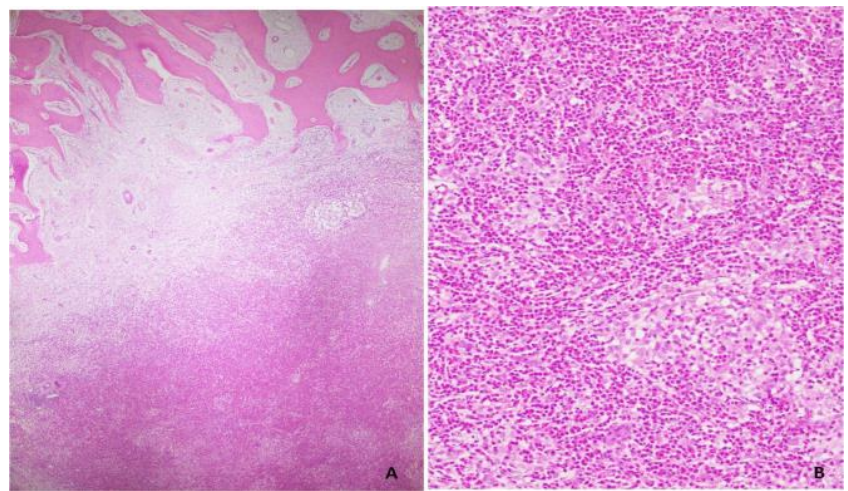

Figure 3: The cellular infiltrate near the bone trabeculae (H\&E, x20) (A), Clusters of histiocytes with a reniform vesiculated nucleus and abundant foamy cytoplasm, and with numerous eosinophil (H\&E, x40) (B) 
Surgery, radiation therapy and chemotherapy are the treatment options, although surgery is usually sufficient for solitary lesions. A wide resection with tumor-free margins is required to provide the best chance of cure.

\section{CONCLUSION}

We report here a rare case in which a solitary $\mathrm{LCH}$ that developed in the rib was successfully treated through a surgical resection. Although uncommon, LCH should be considered in a differential diagnosis of osteolytic lesions in the rib.

\section{CONFLICTS OF INTEREST}

None declared.

\section{AUTHOR CONTRIBUTIONS}

Concept - D.Y., M.S.Y., P.T., C.G.; Planning and Design - D.Y., M.S.Y., P.T., C.G.; Supervision - D.Y., M.S.Y., P.T., C.G.; Funding - D.Y., M.S.Y.; Materials - D.Y.; Data Collection and/or Processing - D.Y., M.S.Y.; Analysis and/or Interpretation - D.Y., P.T., C.G.; Literature Review - D.Y., P.T.; Writing - D.Y., M.S.Y.; Critical Review M.S.Y.

\section{YAZAR KATKILARI}

Fikir - D.Y., M.S.Y., P.T., C.G.; Tasarım ve Dizayn - D.Y., M.S.Y., P.T., C.G.; Denetleme - D.Y., M.S.Y., P.T., C.G.;
Kaynaklar - D.Y., M.S.Y.; Malzemeler - D.Y.; Veri Toplama ve/veya İşleme - D.Y., M.S.Y.; Analiz ve/veya Yorum D.Y., P.T., C.G.; Literatür Taraması - D.Y., P.T.; Yazıyı Yazan - D.Y., M.S.Y.; Eleştirel İnceleme - M.S.Y.

\section{REFERENCES}

1. Azouz EM, Saigal G, Rodriguez MM, Podda A. Langerhans' cell histiocytosis: pathology, imaging and treatment of skeletal involvement. Pediatr Radiol 2005; 35:103-15. [CrossRef]

2. Tsuchie $H$, Okada $K$, Nagasawa $H$, Yano $M$, Naniyo $H$, Shimada $Y$. Langerhans cell histiocytosis of the sternum. Ups J Med Sci 2009; 1 14:121-5. [CrossRef]

3. Kim SH, Choi MY. Langerhans cell histiocytosis of the rib in an adult: A case report. Case Rep Oncol 2016; 9:83-

\section{8. [CrossRef]}

4. Shimoyama T, Kimura B, Nakamura K, Yamada T, Kawachi $\mathrm{H}$. Langerhans cell histiocytosis of the rib in adult male. Kyobu Geka 201 1; 64:135-8.

5. Degar BA, Rollins BJ. Langerhans cell histiocytosis: malignancy or inflammatory disorderdoing a great job of imitating one? Dis Model Mech 2009; 2:436-9. [CrossRef]

6. Weitzman S, Jaffe R. Uncommon histiocytic disorders: the non-Langerhans cell histiocytoses. Pediatr Blood Cancer 2005; 45:256-64. [CrossRef] 